\title{
Encountering COVID-19: Human resource management (HRM) practices in a pandemic crisis \\ Kumudinei Dissanayake
}

Department of Management \& Organization Studies

Faculty of Management \& Finance, University of Colombo, Sri Lanka

\begin{abstract}
Scholars highlight the lack of preparations for unexpected shocks of employment and human resources all over the world, while stressing its possible adverse impacts on work organizations, employees and the economy. Given the prevailing COVID-19 pandemic threat and the dearth of clear findings on how human resource (HR) departments and the HR professionals should encounter a global pandemic, present study aims to examine and inform the basic HR practices to be adopted in a pandemic and prospects for HR professionals in handling such situations. Aim of the study is achieved by reviewing past research findings and relevant information which are available on wider media. Findings suggest a typology of HR practices identified with ' $6 \mathrm{Cs}$ ' for the successful handling of human resources in organizations in a pandemic. Further, the study finds a cluster of post-pandemic HR practices to be used, mostly for the service sector organizations, when attempting human resources recovery.
\end{abstract}

Keywords: COVID-19; Human resource management (HRM) practices; Pandemic crisis; Post-pandemic

\section{Introduction}

Global pandemics though not frequent, but are also not uncommon. Therefore, this is not the first instance the world of work is experiencing a global pandemic. Work organizations in the recent past have experienced global epidemics and encountered the spread of the HPAI A (H5N1) avian influenza virus in 1997 (Hong Kong SAR based), Severe Acute Respiratory Syndrome (SARS) in 2003 (Singapore and China based), infections with H5N1 in 2004 (Vietnam and Thailand based), H1N1 in 2009 (first detected in the USA), A(H7N9) virus in 2013 (China based), and Ebola virus in 201416 (West Africa based) (WHO, 2018; 2020) which threatened the 
workplaces and crippled the economies. This kind of epidemic threats have badly affected the Asian economies, their service sectors and human resource management (HRM), thus leading to negative consequences on employment and psycho-social lives of employees (Lee \& Warner, 2005a; 2005b; 2006).

The coronavirus influenza (COVID 19) (China based) started spreading in the late 2019, has been declared as pandemic and more threatening (Coronavirus Resource Center, 2020; Wan, 2020), while badly influencing the economies, workplaces and human social lives than any other global devastation or spread of a disease happened to experience after the second World War.

The smooth functioning of work organizations has been threatened or obstructed by restraining of human gatherings, imposing of social/ physical distancing, commuting restrictions, travel bans and cancellation or postponement of business meetings. Reporting to work by employees has been challenged with either sickness, appearance of symptoms of the disease, or fear of being sick of coronavirus, under which conditions some were subject to compulsory quarantine or medical isolation. At certain points, they have been asked to undergo self-quarantine. In addition, even healthy employees are burdened with patient-care, elder-care, child-care (familycare) and if not, self-care due to prevailing spread of the disease, closure of nurseries/ schools and/ or even due to leaving of their domestic-helpers.

A study of health-related behaviors in an influenza pandemic in Chinese urban residents found that 38 percent of respondents would stay away from work or school under pandemic circumstances (Yuan et al., 2009). A similar study of health workers (at health departments) on their precautionary behavior in response to perceived threat of pandemic influenza, conducted in the USA, revealed that nearly 50 percent of the workers would avoid work in epidemic situations (Balicer, Omer, Barnett, \& Everly, 2006). A similar but comparative study conducted by Sadique et al. (2007) found 35 percent of Europeans would be absent from work during a pandemic (influenza), where that percentage of the same is higher for Asians as 52 percent. In this backdrop, unavoidably, during this pandemic human resource (HR) managers have to encounter the issues of labor shortage and labor inefficiency at workplaces. Amid this vulnerability, HR departments 
worldwide are compelled to introduce and implement new policies, plans and working modes not only for sustaining the smooth functioning of organizations but also for safeguarding their own employees against the effect of global pandemic.

Lee and Warner (2005a; 2005b; 2006) studying the consequences of SARS epidemic, noted that there were lack of preparations for unexpected shocks of employment and human resources in East Asian countries at the time the SARS was spreading. Lee and Warner (2005b) concluded that "contingency plans must be prepared at both macro-, meso- and micro-economic levels, as well as vis a vis enterprise level HRM" (p.26). Even though a number of studies have been conducted to examine the pandemic responses and preparedness at regional or country level (Cocker, 2009; Junadi, 2009; Philavong, 2009), there exist a dearth of findings on how HR departments of local organizations should act and respond in such situations; both during the pandemic, and post-pandemic. The aim of this study is to examine and inform the basic HR practices to be adopted (during and post-), and prospects for HR professionals in a global pandemic. Thus, this work synthesizes answers to the questions: how the HR departments and HR professionals have encountered epidemics at work organizations in the recent past; and what are the learnings and implications to be drawn for HR professionals to successfully encounter the adverse effects of COVID-19 at workplaces.

Present study is conducted in a period of country lockdown against the threat of spreading coronavirus in the island nation, Sri Lanka. Given the restriction on extending an empirical investigation into the matter of concern, the study aim is achieved through a review of existing literature and together with information available on wider media. The paper is structured as follows. First, it reviews the role of HRM in a pandemic, with reference to the broadbased theoretical underpinnings and existing typologies and models. Followed by a brief elaboration of the method of the study, the paper reviews post-pandemic HR practices with reference to the findings of previous Asian and non-Asian studies. Presenting the prospects for HR professionals based on the present findings, the study concludes with implications for the field of HRM for encountering pandemic, and directions for further research. 


\section{Role of HRM in a pandemic}

\section{Theoretical underpinnings}

Theoretical base for understanding the role of HRM in generic will be supportive in comprehending the same even in a pandemic. Thus, a number of theories confirm the crucial role of HRM and its need of actively engaging with its people even in a pandemic situation. The critical importance of human resource for the organizations in emergency and in normalcy (resource-based view) (Barney, 2001), the unavoidable dependency on human resources at every situation (resource dependency perspective) (Pfeffer \& Salancik, 1978), the non-negatable bond of organizations with their employees throughout their career (psychological contract, agency theory) (Rousseau, 2004; Zhang, Bartram, McNeil, \& Dowling, 2015), and the inherent obligations of HRM towards employees (stakeholder view) (Greenwood \& Simmons, 2004) have been well documented and accepted by the scholarship throughout. These theories imply the role of HRM on complementary bases and in systemic viewpoints (at macro level), however, without addressing the specific actions of the HR managers in particular situations (micro level).

\section{Typologies and models}

The typologies of roles played by HR managers have been identified, particularly in the context of expatriate workers, by approaching from different angles to visualize its diversity. Present study reviews a few of such typologies in order to understand the diverse facets of the roles of an HR manager in dealing with human resources in a pandemic. As such, Welch and Welch (2012) has proposed five-roles typology, as; (a) service provider, (b) policy police, (c) adviser, (d) change agent and (e) welfare officer in which the major dimensions of an HR managers' work role are captured. In these roles, the administrative component, care taker and regulator's job, strategic involvement of the HR manager, driving role of making changes, and the employee champion aspect have been encapsulated. In an attempt to identify the international human resource managers' roles in expatriate evacuation, Fee, McGrath-Champ, and Liu (2013), adopting from Welch and Welch (2012), elaborated how these five roles are supporting an expatriate in an emergency. Their speculation shows that HR managers' role (in 
international emergency situations) encompasses; (a) administering human resources at distance, (b) reducing the psychological isolation and stresses, (c) ensuring adherence to policies, procedures and standards, (d) ensuring resource capabilities to meet strategic needs, and (e) driving changes. Fee and McGrath-Champ (2017), examining the role of HR in protecting expatriates, identified four critical areas that organizations should consider in keeping their expatriate employees safe and secured in a crisis situation. They gave prominence and centrality to building a safety and secured culture which was strengthened by three operations; (a) people services (attending to selection, training, and employee well-being related issues), (b) information services (data collection, monitoring, evaluation and organizational learning), and (c) communication services (communication within, with external parties, and with victims of the crisis) (p. 1967).

This wider background informs us that HR managers are obliged with; (a) performing the typical HR functions, (b) informing and updating employees, (c) facilitating the work process, (d) taking care of the work atmosphere, (e) looking after the psychological wellbeing, and (f) helping adopt to new conditions.

\section{Method}

This paper is based on a review of articles accessed through the online databases of JSTOR, Emerald, and Taylor \& Francis (which were accessible through the University of Colombo library during the country lockdown period). The search was limited to reviews, articles and research papers which were published only in English language, using truncations of search terms such as HRM, pandemic, epidemic, influenza, crisis, and disaster in combination, restricting to the fields of "business", "labor and employment relations", and "management and organizational behavior" published from 2000 to 2020 . Followed by a careful skimming, the materials those did not carry any implications for HR practices in a pandemic/ crisis/ disaster situation or prospects for HR professionals were removed. As a very limited number of articles were remained after adopting this exclusion criteria, a backward referencing and forward referencing of selected key articles were conducted to increase the inclusion, while maintaining the same criteria for selection. As the secondary sources, the websites of World Health Organization (WHO) and the International Labor Organization (ILO) as well 
as news articles appeared timely on HRM and SHRM related Newsletters (online) were reviewed for relevant information.

\section{HRM practices during a pandemic and post-pandemic}

Most of the past studies are reporting post-pandemic practices adopted by companies, however, it is apparent that some of the practices can be well used even during the pandemic situations. This review, irrespective of the time factor, examines HRM practices discussed in the context of influenza epidemic, crisis or disaster situations encountered by public or private sector organizations. Present review has enabled us to comprehend multiple postpandemic HRM practices not necessarily through the HRM perspective, but from a generic management standpoint. As indicated, these can be introduced in a broader sense, as 6Cs which include; (a) curtailing and compensation, (b) communication, (c) coordination and collaboration, (d) creating a caring culture, (e) cleaning and hygiene, and (f) creativity.

\section{Curtailing and compensation}

Service sector and labor-intensive industries of an economy are the hard-hit, and the atypical employees, such as part-time and contract-based employees, are the most vulnerable victims in a pandemic. Such companies are unavoidably compelled to go by selected business unit level strategies like shorten business hours, suspension or closure of business (Lee \& Warner, 2006) at least for a short period. After a financial crisis, the HR practices commonly adopted by Asian companies included shutting down the operations, laying off workers, reducing salary, and freezing recruitment, especially towards the survival of the companies (Ananvoranich \& Tsang, 2004). Following the SARS epidemic in 2003, Chinese, Singaporean and Hong Kong service sector organizations evidenced to several strategies implemented to counter the negative economic and financial consequences they experienced. Accordingly, they stepped in to take a number of costcutting measures through retrenchment strategies, thus, proposing adjustments related to employee compensation, amalgamated with leave policies and lay-off schemes. A short-term HRM strategy used to counter the decline of revenue was lay-off of employees (Lee \& Warner, 2005a; 2005b; 2006). In a post-epidemic survey, Lee and Warner (2005b) identified several reactive HR strategies such as dismissals, voluntary or involuntary lay-offs, 
pay-cuts (temporary or otherwise), unpaid breaks for existing staff, and nopay leave schemes (both voluntary and involuntary) adopted in the hotel sector in China. As noted by Lee and Warner (2005a), most of the staff retrenchment decisions have followed last-in-first-out principle, thus making latest joined staff to be removed first. Some organizations have introduced specified work-hours (required) and no-pay leave (compulsory) for a working month. Not in an epidemic, but in a time of disaster, certain similar HR practices towards staff retrenchment have been reported in the literature (e.g., Mann, 2014). Thus, introduction of shortage pay (adjusting pay to count for labor shortages), pay differentials for employees who work during times of declared disasters, addressing employee furloughs, separate policies to address overtime/ compensation during states of emergency, policies that address employee retention during states of emergency, and streamlined policies for disciplining and terminating employees during states of emergency are included in the list (Mann, 2014).

\section{Communication}

As noted by Lee and Warner (2005b), the decisions on lay-offs, pay-cuts and changed leave systems are of adverse nature and those have been taken under the paternalistic HR practices with proper communications. Despite of these, the issues related to reporting to work, making payments, handling retention and return to work need attention in a time of a disaster. Employee leaves have been a serious matter of concern as their inability to report to work in a crisis/ disaster situation would lead to absence. Therefore, leave policies to be adopted in the organization in such an emergency situation should be extremely clear and well communicated to the entire workforce (Mann, 2014). Maintaining a proper channel of communications with the staff has been a focal point in HR decisions making in the service sector organizations in China during the SARS epidemic (Lee \& Warner, 2005b). Thus, the importance of communication within the workplace, especially when applying the post-pandemic HR practices and policies, has been highlighted in the previous studies. Wu, Lee, and Lin (2012) report, "During a crisis, whether HR is ready to communicate regarding emergencies on behalf of the organization and employees is a sign for employees to access their desire to stay with their employer" (p. 2708). Moreover, frequent and regular communications with employees during a pandemic exhibit to which extent 
the organization is concerned about their health and wellbeing ("How HR", 2020). Jacobson and Sowa (2016) highlighted the need of detailed and frequent communication of the correct information to employees, especially in the case of tough HR decisions made by the management. They have recognized that such communications can be done through certain employees themselves as a mechanism for getting employees 'engaged' in the crisis situation. They further noted that it is a two-way communication in which the feedback also sought from the recipients of the information, thus avoiding the spread of any rumors or misinformation.

\section{Coordination and collaboration}

In addition to compensation related decisions, organizations have moved towards the implementation of certain HR practices through job designing and task restructuring by coordinating through the full workload and collaborating with the entire workforce. Followed by the Asian financial crisis, Thai manufacturing companies had started introducing restructuring of work while increasing the workload for existing employees (Ananvoranich \& Tsang, 2004). Reduced business hours and, sometimes, shortage of labor have led to short-time working initiatives, redeployment and retraining of staff (for different jobs or for different sectors) and restructuring and rescheduling of tasks in organizations in order to get the work done from the existing staff (Lee \& Warner, 2005b). Cross training is also used by organizations for responding to emergency situations (Mann, 2014). As postcrisis HR measures, some organizations have implemented flexible work scheduling, alternative work arrangements, and granting additional time-off for employees as well (Jacobson \& Sowa, 2016), while some recommends these practices to be used during the pandemic (e.g., "COVID-19", 2020a). It seems that the work related HRM practices are context-driven as certain crisis situations required freezing recruitment (Ananvoranich \& Tsang, 2004; Lee \& Warner, 2005a; 2005b; 2006) while other needed immediate hiring of temporary workers (Mann, 2014). At the same time, these decisions should align with the need of the department(s) and should be coordinated among all the departments, and throughout the organization. Mann's study which examined the preparedness for crisis by the HRM of a local government revealed that "clear lines of communication between the HR department and other departments" as well as "collaboration among departments" are crucial in an emergency situation (p. 168). 
practices in a pandemic crisis

\section{Creating a caring culture}

Lee and Warner (2005b), reporting on the consequences of the SARS epidemic in Chinese context, noted the hostile nature of certain HR decisions such as lay-offs, pay-cuts and changed leave systems, and how organizations handled them in a more positive approach. Even though Chinese HR practices are reported to be paternalistic, they had introduced and implemented such decisions with proper caring organizational culture. Among many of the good HR practices introduced by the Chinese service organizations in line with the SARS epidemic were; taking care of the health and safety of the staff, paying special attention on the health conditions of pregnant women, and facilitating them with special leave systems. In order for maintaining a caring organizational culture, the organizations have taken steps in providing financial support for its staff, which came in the form of interest free loan schemes, re-instatement of bonuses, and introducing onemonth discretionary bonus payments. In addition to these, looking into employee training and development aspects after the crisis situation and introducing recreational activities, and employee award systems are also reported under the making of a caring culture (Lee \& Warner, 2005a). In examining the innovative HRM practices of turbulent times, Jacobson and Sowa (2016) found the management is taking measures for responding to immediate morale issues of the employees in municipal organizations. In that, some HR departments stepped into getting employees engaged in managing the existing turbulent environment, addressing the workplace stress, arranging wellness programs, developing new skills, and conducting employee surveys.

In addition, taking care of health and safety of employees at work or out of work becomes another facet of creating a caring culture within the organizations. "COVID-19" (2020a) emphasizes that HR departments should comply with legal requirements to ensure the health and safety of the staff during a pandemic. Presenting the interview highlights of HR professionals, it pinpoints the need of putting employee health and safety in the first priority and going beyond the policy to support employees with empathy. In line with this perspective, HR leaders view that "If people believe and trust that you're showing them care and concern, they will support whatever other initiatives you roll out" (“COVID-19”, 2020a). 
Most of the measures related to compensation and task restructuring such as voluntary or involuntary no-pay leave, voluntary or involuntary pay-cuts, dismissal of staff, redeployment of staff, retraining of staff, restructuring and rescheduling of tasks (Lee \& Warner, 2006) are not bringing positive economic, social or psychological impacts on employees at workplace. Thus, gradual creation of a distressful work environment would be a possibility in a post-pandemic organization. Past studies have proven that some organizations actively engage in addressing and mitigating the workplace stress through counselling programs during the emergency situations (e.g., Mann, 2014). "COVID-19" (2020b) reveals that more than one third of Chinese organizations (35\%) are providing employees with psychological counselling services in the pandemic time.

\section{Cleaning and hygiene}

In the wake of SARS epidemic, organizations had been prompted to maintain a cleaner internal environment within the premises and paying special attention to the health and safety of their employees (Lee \& Warner, 2005a). Under the policy framework for fighting Covid-19 based on International Labor Standards, ILO (2020b) the need of protecting workers and strengthening occupational health and safety measures at workplaces have been stressed. Recent news reports show that workplace cleaning has gained prominence during the current spread of COVID-19 too. Under the HR planning for minimizing the impacts of coronavirus, HR departments are encouraged to make certain cleaning supplies available for the company employees during the pandemic. Accordingly, the items like hand sanitizer, tissues, spray disinfectant, and soap/paper towels can be supplied to employees for ensuring the personal hygiene and environmental cleanliness. Encouraging all employees to use common hygiene best practices (such as sneezing into their arm, covering their mouth when they cough or sneeze, and promptly disposing of used tissues) are also reported under supportive HR practices in dealing with pandemic in organizational environments ("How HR", 2020). Further, it is advised to perform routine environmental cleaning of the workplaces, giving special attention to frequently-touched surfaces. Provision of disposable wipes is also recommended so that employees can clean the commonly used surfaces before used by another person (Dailey \& Mitchell, 2020). 


\section{Creativity}

Work organizations and HR professionals are unprepared for global pandemics. However, when encountered, they cannot negate the obligations towards their employees and the business. Thus, unexpected pandemics stimulate creativity of HR departments. This means, HR department has to be creative in work rescheduling, restructuring, responsibility sharing, teamwork, technology use, adopting new hygiene techniques, and introducing new working modes and so on in a pandemic (Gravett, 2020). For instance, work organizations adopt teleworking as a mode of remote working during the period of Coronavirus ("COVID-19", 2020b). However, ILO (2020a) reports that teleworking is not recommended under all circumstances and for all types of jobs. This reminds us that organizations need to be imaginative and innovative in developing and/ or proposing most appropriate working modes suited to their jobs and workforces. Similarly, task restructuring, rescheduling and even cross training arrangements (Dailey \& Mitchell, 2020) would require creativity not only for achieving efficiency but also for avoiding ambiguity and chaos at work environments.

In line with the above review, a summary of the findings of HR practices adopted during and post-pandemic situations are shown in Tables 1 and 2 respectively. Lee and Warner (2005b) have identified that training and task restructuring have been performed in Chinese companies proactively during an epidemic, while some other practices were used in response to the situation emerged.

Table 1: HRM Practices during a Pandemic

\begin{tabular}{|l|l|}
\hline Timing & HR Practices \\
\hline Proactive & $\bullet$ Training \\
& - Task restructuring \\
\hline Reactive & - Frozen recruitment \\
& - Voluntary / involuntary no-pay leave \\
& - Voluntary / involuntary pay-cuts \\
& - Dismissal of (casual) staff \\
& - Cross training \\
& - Task reorientation \\
& - Pdditional time-off \\
\hline
\end{tabular}




\begin{tabular}{|l|l|}
\hline & - Pay adjustments \\
- Special leave policies \\
- Retention tactics \\
- Flex time working \\
- Diverse modes of remote working (e.g., \\
& - teleworking, work-from-home) \\
- Health and safety measures for staff \\
- Hygiene practices for staff \\
- Psychological counselling
\end{tabular}

The Table 2 below exhibits post-pandemic HR practices adopted in or suggested for work organizations.

Table 2: Post-pandemic HR Practices

\begin{tabular}{|c|c|}
\hline HR Function & HRM Practice \\
\hline $\begin{array}{l}\text { Job design \& Work } \\
\text { scheduling }\end{array}$ & $\begin{array}{ll}\text { - } & \text { Process restructuring } \\
\text { - } & \text { Work rescheduling } \\
\text { - } & \text { Task reorientation } \\
\text { - } & \text { Flexible scheduling } \\
\text { - } & \text { Alternative work schedules (e.g., four-day work } \\
& \text { weeks, flex hours) } \\
\text { - } & \text { Alternative work arrangements (e.g., } \\
& \text { teleworking, job sharing) }\end{array}$ \\
\hline Re-deployment of staff & $\begin{array}{l}\text { - Redeployment of staff for needy departments/ } \\
\text { sectors }\end{array}$ \\
\hline Training & $\begin{array}{l}\text { - Re-training employees in different/ needy } \\
\text { sections/ sectors }\end{array}$ \\
\hline $\begin{array}{l}\text { Incentives for living the } \\
\text { pandemic }\end{array}$ & $\begin{array}{l}\text { - } \quad \text { Year-end bonus } \\
\text { - } \text { Reimbursement of foregone salaries } \\
\text { - } \text { Discretionary bonus } \\
\text { - } \text { Interest-free loan schemes }\end{array}$ \\
\hline Leave & $\begin{array}{l}\text { - Special leave schemes for sacrificed staff } \\
\text { - Additional time-off }\end{array}$ \\
\hline Salaries \& Wages & $\begin{array}{ll}\text { - } & \text { Wage reforms } \\
\text { - } & \text { Introducing more flexible wage systems }\end{array}$ \\
\hline
\end{tabular}




\begin{tabular}{|l|ll|}
\hline Lay-offs & $\bullet \begin{array}{l}\text { Staff lay-offs at certain levels/ sections/ sectors, } \\
\text { or categories, if needed }\end{array}$ \\
\hline Workplace counselling & $\bullet$ & Psychological counselling for employees \\
\hline Recreational activities & $\bullet$ & Social activities to increase team spirit \\
\hline $\begin{array}{l}\text { Preventive safety } \\
\text { measures }\end{array}$ & $\bullet \begin{array}{l}\text { Training for health and safety practices } \\
\text { Safety awards systems }\end{array}$ \\
\hline $\begin{array}{l}\text { Ensure a healthy } \\
\text { organizational culture }\end{array}$ & $\bullet \begin{array}{l}\text { Employee opinion surveys } \\
\text { Preventive measures against future human } \\
\text { resource shocks at (similar) pandemics }\end{array}$ \\
\hline
\end{tabular}

In light of the broader role to be played by HRM when encountering a pandemic, this review has identified six broader HR practices (6Cs) namely; (a) curtailing and compensation, (b) communication, (c) coordination and collaboration, (d) creating a caring culture, (e) cleaning and hygiene, and (f) creativity which are essential for organizations. The first four practices are well aligned with the so far reported typologies of HR roles. However, this review adds on two more important HR practices to the existing typology; 'Cleaning and hygiene' and 'Creativity' when considering pandemic situations.

\section{Prospects for HR Professionals}

Following the challenges of economic, socio-cultural and psychological nature in a post-pandemic environment, most of the organizations naturally face the HR-related issues re-appearing as a cyclical effect, which turns up due to decrease of revenue of the firms. For instance, slow recovery of the firms from financial hardships which emerge as post-pandemic threats such as limited cashflow, reduced investment capacity, and low profits may lead to a weakened capacity for new recruitments, training programs, bonus payments, employee welfare programs etc. Jacobson and Sowa (2016) found that limited resources and recruiting and maintaining a motivated workforce are challenging HRM departments which are experiencing turbulent times. As a part of the cyclical effects, the HR departments are compelled to make tough decisions on their workforces such as hiring freezes and lay-offs (Jacobson \& Sowa, 2016). Nonetheless, organizations are challenged not only with staff limitations but also with the increasing cost of workforce 
health care after a pandemic. A talented top management would need to address these cyclical effects more strategically.

Fielding (2009) elaborates the negative impacts of a pandemic situation on lack of sufficient human resources in organizations. He opines that the impacts of manpower loss will disrupt the supply chain. His report says "If significant staffing losses occur, either due to sickness or death, then the ability to maintain complex organizations such as hospitals will be severely challenged" (p. 106). When healthy employees need to stay home in order to take care of sick family members or with their difficulty in getting to work due to commuting issues, even the supply of other services will be crippled due to breakdown of the supply chain. Further, suspending employees (even temporarily) will reduce person-to-person contact in occupational environments which would badly affect to the communication flows and networks that are essential in a pandemic environment. Fielding continues "[Only] few organizations have contingency plans for this level of disruption" (2009, p. 106). Employee absenteeism would be another significant issue for work organizations even after the settlement of the situation. With reference to the influenza pandemics created in the history, Neu (2009) notes that the "staff absenteeism will be prolonged" if the pandemic outbreak prevails for a longer period.

Despite the availability of diverse HRM practices to be adopted during the pandemic or post-pandemic, in reality, many organizations would stick in their decision-making process when approaching matters related to pay-cuts, lay-offs, and introducing new working modes. One huge impediment is the lack of provisions in the existing labor policies and legislations for dealing with such unexpected and unplanned circumstances (Shira \& Associates, 2020). Accordingly, paying salary in a work stoppage, suspension of payments, imposing/ adopting new leave schemes, and termination of employment in pandemic situations would require legal provisions (Shira \& Associates, 2020). Organizations may refer to the International Labor Organization's (ILO) guides in this regard (ILO, 2020b).

As highlighted in an influenza pandemic preparedness plan in Thailand (Phoolcharoen, 2009), organizations are required to set up standard operating procedures in advance as a precautionary measure. In addition, there are certain important measures to be taken in relation to communication among 
public including employees in organizations. Noted among them are; publicizing information and creating knowledge on the prevention and care of the disease, developing risk communication skills for the people concerned, setting up working groups and officially communicating and coordinating on the provision of information to the people, and formulating a communications plan with the use of public communications tools at the national and local levels (Phoolcharoen, 2009). Information, socialization, communication and education have been identified as part of the strategies for influenza pandemic preparedness in Indonesia (Junadi, 2009). "COVID19" (2020c) recommends HR leaders to; provide direction, confidence and resilience to employees through regular communications and maintain an open dialogue (e.g., communicating a plan of action on the COVID-19 outbreak), contextualize coronavirus for the organization (being a trusted source for accurate and up-to-date information provider on coronavirus and how it is impacting the organization), encourage intentional peer-to-peer interactions (for maintaining regular professional and personal interactions not face-to-face - with their peers), establish team guidelines (for remote work), and provide flexibility for the employees' remote work needs (let them make choices when returning to work e.g., when and how many work hours).

Looking from disaster management perspective into the challenges created by Indian Ocean Tsunami in 2004 on strategic human resource management of multinational non-profit enterprises (MNNPEs), Merlot and Cieri (2012) identified both a series of internal factors (such as capacity of people, skills and internal communication) as well as external factors (such as responses from the external parties and coordination) that affected the successful handling of human resources. Thus, institutions should strengthen linkages, set up partnerships with all stakeholders in all the sectors (public, private and civil society), share information, knowledge, good practices and lessons learned, give leadership and coordinate properly in the situation in order to manage the pandemic (Philavong, 2009).

\section{Conclusion and implications}

When encountering the COVID-19 pandemic, work organizations will be immensely benefitted and strengthened if they are acquainted with the 6Cs typology of HR practices. While recognizing the value of specific HR 
functions and practices, HR managers would require to pay more attention on the generic practices of curtailing and compensation, communication, coordination and collaboration, creating a caring culture, cleaning and hygiene, and creativity in a pandemic environment.

Planning for pandemic situations must be on the agenda of every organization. Osterholm (2005) writes "every school board, manufacturing plant, investment firm, mortuary, state legislature, and food distributor" must have such a plan in their agenda (p. 35). Thus, irrespective of the scale of the business, the nature of the industry, or the location, every organization should be ready with its own plan for unexpected pandemics. By maintaining an updated skill inventory of its (diverse) workforce, the HR departments will be able to identify the people with required skills for acting in a needy situation, and it will be helpful in task re-orientation in a crisis situation.

It is no doubt that organizations should follow-up the health and safety conditions of their employees in a pandemic. However, as was visible in Sri Lanka, the (central) government took almost the total responsibility of looking after the health and welfare of the populace (with the capacity and strength of the security forces and the national police) instead of organizations taking the responsibility of checking the wellbeing of their employees. It is true that the HR function of most of the organizations are not prepared for the impact of such catastrophe like a global influenza pandemic. Still, it is apparent that COVID-19 encounter is teaching/ reminding the HR function of organizations of the forgotten or neglected obligations towards employee health and wellbeing to be maintained in the out-of-work environments too. With reference to the HR practices reviewed, it should be noted that none of the reviewed literature hinted on any HR practice or policy designed for/ thought of differently-abled employees, which could be of high value on socio-cultural and ethical grounds.

Scholars point out that crisis is both a difficulty and an opportunity. Crisis situations provide companies with opportunities for successfully implementing certain HRM practices which were not feasible in the past (Ananvoranich \& Tsang, 2004; Dailey \& Mitchell, 2010; Jacobson \& Sow, 2016). Thus, the COVID-19 pandemic experience too would be utilized by companies in introducing/ implementing/ adopting certain good/ innovative HR practices which were neglected/ postponed/ not in use before. 
A detailed study of empirical nature, approaching the HR departments and HR managers would bring us more information and the dynamics of HR practices in action in the reality. Such an investigation would reveal the challenges faced by HR managers and the departments in a pandemic situation, which will open more avenues for learning lessons and be prepared for future unexpected devastations relevant to work organizations.

\section{References}

Ananvoranich, O., \& Tsang, E. W. K. (2004). The Asian financial crisis and human resource management in Thailand: The impact on equity perceptions. International Studies of Management \& Organization, 34(1), 83-103. Retrieved on 07/04/2020 through https://www. jstor.org/stable/40397586

Balicer, R. D., Omer, S. B., Barnett, D. J., \& Everly, G. S. Jr. (2006). Local public health workers' perceptions toward responding to an influenza pandemic. BMC Public Health, 6(99). Retrieved on $07^{\text {th }}$ April 2020 through https://bmcpublichealth.biomedcentral.com/track/pdf/ 10.11 86/1471-2458-6-99. doi:10.1186/1471-2458-6-99

Barney, J. B. (2001). Is the resource-based 'view' a useful perspective for strategic management research? Yes, Academy of Management Review, 26(1), 41-56.

Bondarouk, T., Parry, E., \& Furtmueller, E. (2017). Electronic HRM: four decades of research on adoption and consequences. The International Journal of Human Resource Management, 28(1), 98-131, DOI: 10.1080/09585192.2016.1245672

Cocker, R. (2009). What is Pandemic Influenza Preparedness? Definitions, Best Practices and Gaps. In M. Caballero-Anthony (ed.), Pandemic preparedness in Asia, (pp. 27-34), RSIS Monograph Series, No. 16, S. Rajaratnam School of International Studies. Retrieved through https://www.jstor.org/stable/resrep05905.7

Coronavirus Resource Center (2020). Johns Hopkins University \& Medicine. Website. Retrieved on $30^{\text {th }}$ March 2020 through https://coron avirus .jhu.edu/ 
COVID-19: Coronavirus: HR's role in business continuity plans (2020a). Human Resource Director. Retrieved through https://www. hcamag.com/asia/specialisation/workplace-health-and-safety/ coronavirus-hrs-role-in-business-continuity-plans/214865

COVID-19: How has HR tweaked their strategy? (2020b). Human Resource Director. Retrieved on $31^{\text {st }}$ March 2020 through https://www.hcam ag.com/asia/news/general/covid-19-how-has-hr-tweaked-theirstrategy/217964

COVID-19: Top priorities for HR leaders revealed (2020c). Human Resource Director. Retrieved on $31^{\text {st }}$ March 2020 through https://www.hcamag.com/asia/specialisation/employeeengagement/covid-19-top-priorities-for-hr-leaders-revealed/217508

Dailey, A. M. \& Mitchell, J. O (March 10, 2020). Helping human resources managers prepare for coronavirus pandemic. The National Law Review, Retrieved on $10^{\text {th }}$ April 2020 through https://www.natlawreview. com/article/helping-human-resources-managers-prepare-coronaviruspandemic

Fee, A., \& McGrath-Champ, S. (2017). The role of human resources in protecting expatriates: insights from the international aid and development sector. The International Journal of Human Resource Management, 28(14), 1960-1985, DOI: 10.1080/09585192.2015. 1137617

Fielding, R. (2009). Continuity in crisis: Multi-sectoral pandemic preparedness. In M. Caballero-Anthony (ed.), Pandemic preparedness in Asia, (pp. 27-34), RSIS Monograph Series, No. 16, S. Rajaratnam School of International Studies. Retrieved through https://www. jstor.org/stable/resrep05905.9

Gravett, W. (2020). What HR managers should know about COVID-19. Walden University Homepage. Retrieved on 02/04/2020 through https://www.waldenu.edu/online-masters-programs/ms-in-humanresource-management/resource/what-hr-managers-should-knowabout-covid-19 
Greenwood, M. R., \& Simmons, J. (2004). A stakeholder approach to ethical human resource management. Business \& Professional Ethics Journal, 23(3), 3-23.

How HR planning can minimize COVID-19 business impacts (2020). Suitless. Retrieved on 31/03/2020 through https://www.getsuitless. com/how-hr-planning-can-minimize-covid-19-business-impacts/

International Labor Organization (ILO) (2020a). COVID-19: Protecting workers: Keys for effective teleworking during the COVID-19 pandemic. ILO website. Retrieved on 02/04/2020 through https:// www.ilo.org/global/about-the-ilo/newsroom/news/WCMS 739879 llang--en/index.htm

International Labor Organization (ILO) (2020b). What are the key policies that will mitigate the impacts of COVID-19 on the world of work? ILO Website. Retrieved on 02/04/2020 through https:// www. ilo.org/global/topics/coronavirus/impacts-and-responses/WCMS 739048/lang--en/index.htm

Jacobson, W. S., \& Sowa, J. E. (2016). Municipal human resource management: Challenges and innovative practices in turbulent times. State \& Local Government Review, 48(2), 121-131. Retrieved on $07^{\text {th }}$ April 2020 through https://www.jstor.org/stable/44651988

Junadi, P. (2009). Pandemic preparedness operations, systems and networks: The Indonesian case. In M. Caballero-Anthony (ed.), Pandemic preparedness in Asia, (pp. 27-34), RSIS Monograph Series, No. 16, S. Rajaratnam School of International Studies. Retrieved through https://www.jstor.org/stable/resrep05905.9

Lee, G. O. M., \& Warner, M. (2005a). Epidemics, labour markets and unemployment: the impact of SARS on human resource management in the Hong Kong service sector. The International Journal of Human Resource Management, 16(5), 752-771, DOI: 10.1080/095851905000 83202

Lee, G. O. M., \& Warner, M. (2005b). The Consequences of the SARS Epidemic for China's Employment and Human Resources. The 
Journal of Comparative Asian Development, 4(1), 9-28, DOI: 10.1080/15339114.2005.9678408

Lee, G. O. M., \& Warner, M. (2006). Human resources, labour markets and unemployment: The Impact of the SARS epidemic on the service sector in Singapore. Asia Pacific Business Review, 12(4), 507-527, DOI: $10.1080 / 13602380600571443$

Mann, S. (2014). Human resources and emergency planning: preparing local governments for times of crisis. Public Administration Quarterly, 38(2), 163-205. Retrieved on $07^{\text {th }}$ April 2020 through https://www. jstor.org/stable/24372052

Merlot, E. S., \& Cieri, H. D. (2012). The challenges of the 2004 Indian Ocean tsunami for strategic international human resource management in multinational nonprofit enterprises. The International Journal of Human Resource Management, 23(7), 1303-1319, DOI: 10.1080/ 09585192.2011.610337

Osterholm, M. (2005). Preparing for the next pandemic. Foreign Affairs, 84(4), 24-37. Retrieved on $07^{\text {th }}$ April 2020 through https:// www.jstor.org/stable/20034418.

Pfeffer, J. \& Salancik, G. R. (1978). The external control of organizations: A resource dependence perspective. New York: Harper \& Row Publishers.

Philavong, B. (2009). ASEAN cooperation in pandemic preparedness and response. In M. Caballero-Anthony (ed.), Pandemic preparedness in Asia, (pp. 35-42), RSIS Monograph Series, No. 16, S. Rajaratnam School of International Studies. Retrieved on $07^{\text {th }}$ April 2020 through https://www.jstor.org/stable/resrep05905.8

Phoolcharoen, W. (2009). Thailand's pandemic preparedness: Operations, systems and frameworks. In M. Caballero-Anthony (ed.), Pandemic preparedness in Asia, (pp. 35-42), RSIS Monograph Series, No. 16, S. Rajaratnam School of International Studies. Retrieved on $07^{\text {th }}$ April 2020 through https://www.jstor.org/stable/resrep05905.10 
Rousseau, D. M. (2004). Psychological contracts in the workplace: Understanding the ties that motivate. The Academy of Management Executive, 18(1), 120-127.

Sadique, M. Z., Edmunds, W. J., Smith, R. D., Meerding, W. J., de Zwart, O., Brug, J., \& Beutels, P. (2007). Precautionary behavior in response to perceived threat of pandemic influenza. Emerging Infectious Diseases, 13(9), 1307-1313. https://doi.org/10.3201/eid1309.070372

Shira, D. \& Associates (2020). COVID-19: Managing your human resources in Vietnam. Vietnam Briefing. Newsletter. Retrieved on $31^{\text {st }}$ March 2020 through https://www.vietnam-briefing.com/news/covid-19managing-human-resources-vietnam.html/

Wan, W. (20 March 2020). WHO declares a pandemic of coronavirus disease covid-19. The Washington Post. Retrieved on $07^{\text {th }}$ April 2020 through https://www.washingtonpost.com/health/2020/03/11/whodeclares-pandemic-coronavirus-disease-covid-19/

Welch, C. L., \& Welch, D. E. (2012). What do HR managers really do? HR roles on international projects. Management International Review, 52, $597-617$.

Wilkinson, A., \& Wood, G. (2017). Global trends and crises, comparative capitalism and HRM. The International Journal of Human Resource Management, 28(18), 2503-2518, DOI: 10.1080/09585192.2017. 1331624

World Health Organization (WHO) (2018). Influenza (Avian and other zoonotic). WHO Homepage. Retrieved on $08^{\text {th }}$ April 2020 through https://www.who.int/news-room/fact-sheets/detail/influenza-(avianand-other-zoonotic)

World Health Organization (WHO) (2020). Ebola virus disease. WHO Homepage. Retrieved on $09^{\text {th }}$ April 2020 through https://www.who.int/news-room/fact-sheets/detail/ebola-virus-disease

Wu, C., Lee, W., \& Lin, R. S. J. (2012). Are employees more committed and willing to accept critical assignments during a crisis? A study of organizational commitment, professional commitment and willingness 
to care during the SARS outbreak in Taiwan. The International Journal of Human Resource Management, 23(13), 2698-2711, DOI: 10.1080/09585192.2011.637056

Yuan, J., Zhang, L., Xu, W., Shen, J., Zhang, P., \& Ma, H. (2009). Reported changes in health-related behaviours in Chinese urban residents in response to an influenza pandemic. Epidemiology and Infection, 137(7), 988-993. Retrieved on $07^{\text {th }}$ April 2020 through https://www.jstor.org/stable/30221706

Zhang, M. M., Bartram, T., McNeil, N., \& Dowling, P. J. (2015). Towards a research agenda on the sustainable and socially responsible management of agency workers through a flexicurity model of HRM. Journal of Business Ethics, 127(3), pp. 513-523. 